\title{
Physicochemical and Antioxidant Properties of Banana Varieties and Sensorial Evaluation of Jelly Prepared from those Varieties Available in Sylhet Region
}

\author{
Abdullah A. SaD ${ }^{a}$, M. M. Hoque ${ }^{a}$, And Wahidu Zzaman ${ }^{a^{*}}$ \\ ${ }^{a}$ Department of Food Engineering and Tea Technology, Shahjalal University of Science and Technology, \\ Sylhet-3114, Bangladesh \\ ${ }^{*}$ Corresponding author \\ wahid-ttc@sust.edu
}

Received: 12 January 2018; Published online: 18 October 2018

\begin{abstract}
The present research aimed to evaluate and compare the antioxidant activity in both pulp and peel and the physicochemical contents in the pulp of four local varieties of banana, i.e. Musa acuminate species named Sagor, Champa, Shail and Bichi, available in Sylhet region of Bangladesh. The antioxidant activity from a methanolic extract of banana peels and pulps was evaluated by determination of total phenolic content and DPPH scavenging activity. The physicochemical contents of banana pulp such as protein, fat, moisture, ash and carbohydrate were also determined. The results showed that the overall antioxidant activity of banana peel was higher than the pulp of banana. The pulp of the Shail variety had the highest antioxidant activity ( $\mathrm{TPC}=80.14 \mathrm{mg}$ GAE/100 $\mathrm{g}, \mathrm{DPPH}$ radical scavenging activity $=91.37 \%$ ) among the four varieties. Fat $(1.38 \%)$ and moisture $(76.23 \%)$ contents were higher in the pulp of Shail, while protein $(1.82 \%)$ and carbohydrate $(22.71 \%)$ contents were higher in the pulp of Bichi. The Champa variety contained higher ash content (1.05\%). Among the jellies prepared from those banana varieties, the jelly of the Shail variety showed the highest score for overall acceptance (6.8) whilst the jelly prepared from the Bichi variety showed the highest score for taste (7.75). This may be due to higher carbohydrate content. The study suggests that banana peel could be used in the food industry as a raw material to produce bakery products and in cosmetics and pharmaceutical industries as an antioxidant supplement.
\end{abstract}

Keywords: Banana; Antioxidant; Physicochemical; Sensory; Sylhet

\section{Introduction}

Bananas are the creamy flesh and sweet fruit, with firmness, which are packaged in their yellow jackets. Banana is one of the most consumed fruits in the world (Alkarkhi, Saifullah, Yong, \& Azhar, 2010).

Nutritionally, banana is a good source of minerals, vitamins, flavonoids, carbohydrate and phenolic compounds (Aurore, Parfait, \& Fahrasmane, 2009). People of all classes of society can easily get banana. Banana can be utilized in the treatment of pains, intestinal lesions of colitis, inflammation and snakebite (Coe \& Anderson, 1999). Diabetes mellitus is treated by the methanolic extract from banana.

In our body, free radicals may be produced continuously which cause serious diseases, like heart disease, cancer, arthritis, inflammation and aging. Antioxidants are those agents which can scavenge the free radicals and inhibit the damage caused by them. Musa spp. (banana) is the world's leading fruit and in terms of economic value, it is the number five agricultural crop in 
world trade. Banana contains antioxidants and phytochemicals such as Vitamin-C, Vitamin-E, flavonoids and $\beta$-carotene (Macheix, Fleuriet, \& Billot, 1990) which have free radical scavenging activity. Some enzymes of banana flesh increase the antioxidant capacity (Someya, Yoshiki, \& Okubo, 2002). That is why, banana consumption is so important to reduce the risk of those diseases. Since banana is a tropical plant, it is able to prevent the oxidative stress that is caused by sunlight of high intensity and the elevated temperature by means of increasing the antioxidant ability (Kanazawa \& Sakakibara, 2000). Banana's antioxidant ability depends on cultivar, maturity and the stage of ripening. The ripening process of banana influences the changes in the antioxidant capacity (Sisler, Alwan, Goren, Serek, \& Apelbaum, 2003).

The peel of banana is one of the main agricultural wastes that is being used in soap making, medicine, animal feed, fillers in rubber and blackening of leather (Olalekan \& Ayodeji, 2010). It is about $40 \%$ of the total weight of the banana (Anhwange, Ugye, \& Nyiaatagher, 2009). There is an increasing quantity of banana peel, much of which goes unused and is disposed of as waste at a large expense. That is why, it is important to find applications for this huge amount of banana peels to minimize environmental problems (Zhang, Whistler, BeMiller, \& Hamaker, 2005). The banana peel is a good source of phenolic compounds which are considered to act as antioxidants against heart disease and cancer (Someya et al., 2002). The banana peel contains different antioxidant compounds, including gallocatechin (Someya et al., 2002) and dopamine (Umamaheswari \& Chatterjee, 2008). In banana peel, the total phenolic compounds range from 0.90 to 3.0 g/100 g dry weight (Someya et al., 2002; Nguyen, Ketsa, \& van Doorn, 2003). Gallocatechin exists at a concentration of $160 \mathrm{mg} / 100 \mathrm{~g}$ dry weight (Someya et al., 2002). Many other phytochemicals like delphinidin, anthocyanin, cyanidin and catecholamines (Kanazawa \& Sakakibara, 2000) are found in ripe banana pulp and peel. According to Someya et al. (2002), total phenolics are higher in banana peel $(907 \mathrm{mg} / 100 \mathrm{~g}$ dry wt.) than in the pulp of banana $(232 \mathrm{mg} / 100 \mathrm{~g}$ dry wt.).

The present study aimed to compare the physico- chemical and antioxidant properties of both peel and pulp of banana varieties found in the Sylhet region of Bangladesh and to evaluate the sensorial properties of jelly prepared from those varieties.

\section{Materials and Methods}

\subsection{Sample collection}

The banana samples (Sagor, Champa, Shail, and Bichi varieties) were collected from the local market of Bondor, Sylhet in Bangladesh.

\section{Sample extraction and preparation}

Two types of samples were prepared from banana. One was from banana peel and the other was from banana pulp. At first the four types of bananas were peeled. Then, the peels of the banana varieties were dried in a freeze dryer for $12 \mathrm{~h}$. The dried samples were powdered using a blender. Then $1 \mathrm{~g}$ from each dried powder was taken in a falcon tube and dissolved into $30 \mathrm{ml}$ methanol for each sample. The samples were then centrifuged at $3000 \mathrm{rpm}$ for 5 minutes. Then, the banana peel samples were filtered.

The samples from banana pulps were prepared by taking $1 \mathrm{~g}$ of banana pulp from each variety and dissolved into $15 \mathrm{ml}$ methanol for each sample in a falcon tube. Then, the samples were centrifuged at $3000 \mathrm{rpm}$ for 5 minutes. After centrifuging, the banana pulp samples were filtered.

\subsection{Antioxidant activity determination by UV-vis spectrophotometer}

The antioxidant activity of banana peels and pulps were evaluated by determination of: (1)total phenolic content and (2) DPPH scavenging activity.

\section{Total phenolic content determination by spectrophotometer}

The total phenolic content was determined by using the Folin-Ciocalteu phenol reagent as reported by Amorim et al. (2008). $0.5 \mathrm{ml}$ of the 
sample extract of four banana varieties, including both banana peel and pulp, was added to 8.5 $\mathrm{ml}$ of distilled water separately. $0.5 \mathrm{ml}$ of the Folin-Ciocalteu phenol reagent was then added to each sample and kept at room temperature for 5 minutes. After that, $1 \mathrm{ml}$ of $35 \%$ sodium carbonate solution was added to each sample. Then the mixtures were shaken well, and kept at room temperature for 20 minutes. The absorbance of the mixtures was then measured at $765 \mathrm{~nm}$. A blank was prepared using distilled water. Then, a set of Gallic acid standard solutions was read against a blank. The results of phenolics were expressed in terms of Gallic acid in $\mathrm{mg} / \mathrm{g}$ of dry extract. Total phenolic contents of banana varieties including both banana peel and pulp were determined as $\mathrm{mg}$ of Gallic acid equivalent per gram using the equation obtained from a standard Gallic acid calibration curve $\left(\mathrm{R}^{2}=0.999\right)$.

\section{DPPH radical scavenging activity determination by spectrophotometer}

The DPPH radical scavenging activity of banana varieties was measured using the modified method described by Chang et al. (2001). $2 \mathrm{ml}$ of $0.2 \mathrm{mM}$ methanol DPPH solution was added to $2 \mathrm{ml}$ of each solution which were extracted from both banana peel and pulp. Then the mixtures were vortexed vigorously for 1 minute and left to stand at room temperature for 10 minutes in the dark for the reaction to occur. After 10 minutes, absorbance was measured against a blank at $517 \mathrm{~nm}$. The ability to scavenge the DPPH radical was calculated using the following formula:

$$
D P P H(\%)=1-\frac{\text { Sample_absorbance }}{\text { Control_absorbance }} \times 100
$$

\subsection{Physicochemical properties}

For proximate analysis, the protein of pulp of the banana varieties was determined by the MicroKjeldahl method as described by Association of the Official Analytical Chemists (2004). A protein conversion factor of 5.2 was used to calculate the percent protein from the Nitrogen determination. The fat content of pulp of the banana varieties was determined according to the method of Ravichandran and Parthiban (2000). In this method, Chloroform/Methanol (2:1) solution was added toeach sample to separate the fat content from the banana pulp. The moisture content of pulp of the banana varieties was determined according to the official method 4401 of American Association of Cereal Chemists (2000). The total ash of banana varieties was measured by direct incineration of each sample in a crucible, according to American Association of Cereal Chemists (2000) method 08-01. The carbohydrate content of the banana varieties was calculated by subtracting the protein, fat, moisture and ash contents from 100 (Lim, Lim, \& Tee, 2007).

\subsection{Sensory analysis}

Jellies were made from the banana pulp of those varieties available in Sylhet region. Sensory evaluation was conducted using a 7 point hedonic scale $(1=$ dislike very much to $7=$ like very much $)$ in order to determine the acceptance of jelly by consumers. The sensory evaluation panel comprised thirty professors and students from Shahjalal University of Science and Technology, Sylhet, Bangladesh. Among the panel members, twenty were men and ten were women, and their age ranged from 18-45. Panel members met the following criteria: have affinity for the consumption of banana, able to feel the basic tastes, possess the ability to recognize aroma and smell, non-smoking, interested in this study and willing to reveal their decisions (Plemmons \& Resurreccion, 1998). The attributes for the sensory evaluation were color, aroma, bitterness, taste and overall acceptance.

\subsection{Statistical analysis}

The experiments were performed in triplicate and data attained from experiments were collated and analyzed using the Statistical Package for the Social Sciences (Version 21; IBM Corporation). The mean scores were calculated for each attribute and one-way analysis of variance, using the Duncan test, was carried out (Maisuthisakul, Suttajit, \& Pongsawat- 
manit, 2007). Significant differences were determined at $\mathrm{p}<0.05$.

\section{Results and Discussions}

\subsection{Antioxidant activity}

\section{Total phenolic content}

Phenolic compounds are essential fruit constituents since they inactivate lipid free radicals or prohibit decomposition of hydroperoxides to free radicals (Maisuthisakul et al., 2007). Table 1 shows that the total phenolic content (TPC) of tested banana varieties varied significantly $(\mathrm{p}<0.05)$ from 7.47 to $80.14 \mathrm{mg}$ GAE/100 $\mathrm{g}$ for banana pulp and from 34.43 to $119.47 \mathrm{mg}$ $\mathrm{GAE} / 100 \mathrm{~g}$ for banana peel. In the present study, methanol was used, which resulted in higher extraction yields of phenolic compounds due to its high polarity. The banana peel has a higher total phenolic content than the pulp of banana. The TPC of banana pulp recorded in the literature were $56.1 \mathrm{mg} \mathrm{GAE} / 100 \mathrm{~g}$ (Sun, Chu, $\mathrm{Wu}$, \& Liu, 2002), 51 to $54 \mathrm{mg}$ GAE/100 g in Pisang Mas banana (Lim et al., 2007; Alothman, Bhat, \& Karim, 2009) and $90.4 \mathrm{mg}$ GAE/100 g in Pisang Awak banana (Choo \& Aziz, 2010). The TPC of pulp from the Sagor variety (7.47 mg GAE/100 g) was not in agreement with previous studies. The value may differ since it is a different variety. According to Fatemeh, Saifullah, Abbas, and Azhar (2012), the TPC was generally higher in the peel than in the pulp for a particular banana component which supports the present study.

\section{DPPH radical scavenging activity}

DPPH radicals react with reducing agents when the electrons pair off and the color of solution is lost stoichiometrically, which depends on the number of electrons taken up (Subhasree, Baskar, Keerthana, Susan, \& Rajasekaran, 2009). The ability of banana peel extracts to scavenge DPPH radicals had been demonstrated (Okonogi, Duangrat, Anuchpreeda, Tachakittirungrod, \& Chowwanapoonpohn, 2007). Therefore, the DPPH scavenging activity of each sample was reported as the percentage of DPPH inhibition, where a higher value is associated with a stronger antioxidant activity (Fatemeh et al., 2012). As the condensation of phenolic compounds increased, the DPPH radical scavenging activity also increased (Alothman et al., 2009; Gonzalez-Montelongo, Gloria Lobo, \& Gonzalez, 2010) which is typical for plant materials. The DPPH radical scavenging activity of various banana pulp extracts are shown in Table 1. The DPPH radical scavenging activity was highest in the pulp of Shail $(91.37 \pm 0.05 \%)$ and the peel of Shail $(94.04 \pm 0.73 \%)$ although the peel of all varieties contained similar values. According to Baskar et al. (2011), the DPPH radical scavenging activity of banana was $98.19 \%$ at $10 \mathrm{mg} \mathrm{ml}^{-1}$. It is evident that the extract obtained from the peel has higher antioxidant activity than that obtained from the pulp (Fatemeh et al., 2012).

\subsection{Physicochemical properties}

Proximate analysis provides information on the basic chemical composition of agricultural waste (Adeolu \& Enesi, 2013). The carbohydrate, protein, fat and energy contents of banana were reported as higher than those of apple (Auta \& Kumurya, 2015). The protein content of banana varieties ranged from $1.28 \%$ to $1.82 \%$ as shown in Table 2. The maximum protein content $(1.82 \%)$ was in the Bichi variety and the minimum was in the Shail variety. Champa and Sagor varieties contained almost equal amounts of protein. The percentage of crude protein for banana was 7.30 according to Auta and Kumurya (2015). The protein content of banana reported in the previous study is higher than the present study due to regional differences. The fat content in banana varieties is also shown in Table 2. This attribute may be used as the basis to confirmiprocessing temperatures and autooxidation that may lead to rancidity which affects the flavour of food (Adeolu \& Enesi, 2013). The fat content of banana varieties ranged from $0.98 \%$ to $1.38 \%$. The Shail variety contained the highest amount of fat (1.38\%) among the four banana varieties while the Sagor variety contained the lowest fat content $(0.98 \%)$. According to the 
Banana varieties available in Sylhet region $\mid 93$

Table 1: Total phenolic content and DPPH radical scavenging activity of different banana peel and pulp

\begin{tabular}{lcccc}
\hline Antioxidant Activity & Sagor & Champa & Shail & Bichi \\
\hline $\begin{array}{l}\text { Total phenolic content of } \\
\text { banana peel (mg GAE } / 100 \mathrm{~g})\end{array}$ & $\mathbf{1 1 9 . 4 7} \pm \mathbf{4 . 7 7 ^ { d }}$ & $70.03 \pm 2.7^{c}$ & $35.88 \pm 3.37 \mathrm{~b}$ & $34.43 \pm 1.43^{a}$ \\
$\begin{array}{l}\text { Total phenolic content of } \\
\text { banana pulp (mg GAE/100 g) }\end{array}$ & $7.47 \pm 0.94^{a}$ & $38.92 \pm 0.58^{c}$ & $\mathbf{8 0 . 1 4} \pm \mathbf{4 . 1 1}$ & $9.8 \pm 0.38^{b}$ \\
$\begin{array}{l}\text { DPPH radical scavenging } \\
\text { activity of banana peel (\%) }\end{array}$ & $93.26 \pm 0.12^{b}$ & $93.54 \pm 0.09^{b}$ & ${\mathbf{9 4 . 0 4} \pm \mathbf{0 . 7 3}^{b}}^{b}$ & $92.27 \pm 0.05^{a}$ \\
$\begin{array}{l}\text { DPPH radical scavenging } \\
\text { activity of banana pulp (\%) }\end{array}$ & $64.49 \pm 0.25^{b}$ & $90.83 \pm 0.44^{c}$ & ${\mathbf{9 1 . 3 7} \pm \mathbf{0 . 0 5}^{c}}$ & $62.14 \pm 3.23^{a}$ \\
\hline
\end{tabular}

Values are mean \pm standard deviation. Within column values followed by different superscript letter(s) are significantly different $(\mathrm{p}<0.05)$.

Table 2: Proximate analysis of various banana pulps

\begin{tabular}{|c|c|c|c|c|}
\hline Composition & Sagor & Champa & Shail & Bichi \\
\hline Protein (\%) & $1.45 \pm 0.05^{a}$ & $1.46 \pm 0.03^{a}$ & $1.28 \pm 0.02^{a}$ & $1.82 \pm 0.06^{a}$ \\
\hline Fat $(\%)$ & $0.98 \pm 0.06^{a}$ & $1.17 \pm 0.09^{b}$ & $1.38 \pm 0.08^{c}$ & $1.29 \pm 0.04 \mathrm{~b}$ \\
\hline Moisture (\%) & $75.47 \pm 0.05^{b}$ & $76.13 \pm 0.34^{c}$ & $76.23 \pm 0.17^{c}$ & $73.49 \pm 0.49^{a}$ \\
\hline $\operatorname{Ash}(\%)$ & $0.96 \pm 0.005^{n s}$ & $1.05 \pm 0.350^{n s}$ & $0.75 \pm 0.007^{n s}$ & $0.72 \pm 0.008^{n s}$ \\
\hline Carbohydrate (\%) & $21.13 \pm 0.13^{b}$ & $20.17 \pm 0.76^{a}$ & $20.37 \pm 2.11^{a}$ & $\mathbf{2 2 . 7 1} \pm 0.04^{c}$ \\
\hline
\end{tabular}

Values are mean \pm standard deviation. Within column values followed by different superscript letter $(\mathrm{s})$ are significantly different $(\mathrm{p}<0.05)$.

Table 3: Sensory evaluation of jelly

\begin{tabular}{|c|c|c|c|c|}
\hline Sensory Attribute & Sagor & Champa & Shail & Bichi \\
\hline Color & $5.2 \pm 0.42^{b}$ & $6.33 \pm 0.52^{c}$ & $5.67 \pm 0.52^{b}$ & $4.5 \pm 0.53^{a}$ \\
\hline Aroma & $5.75 \pm 0.46^{b}$ & $4.8 \pm 0.79^{a}$ & $5.8 \pm 0.79^{b}$ & $6.4 \pm 0.52^{c}$ \\
\hline Bitterness & $3.6 \pm 0.49^{n s}$ & $4.2 \pm 0.42^{n s}$ & $4.5 \pm 0.53^{n s}$ & $3.75 \pm 0.46^{n s}$ \\
\hline Taste & $6.25 \pm 0.46^{b}$ & $4.6 \pm 0.51^{a}$ & $6.5 \pm 0.5^{b}$ & $6.75 \pm 0.46^{c}$ \\
\hline Overall acceptance & $6.20 \pm 0.78^{c}$ & $5.25 \pm 0.88^{a}$ & $6.8 \pm 0.42^{c}$ & $5.4 \pm 0.84^{b}$ \\
\hline
\end{tabular}

Values are mean \pm standard deviation. Within column values followed by different superscript letter(s) are significantly different $(\mathrm{p}<0.05)$. 
USDA National Nutrient data base, the fat percentage of banana pulp was $1 \%$ which is similar to the present value. Auta and Kumurya (2015) reported that the crude fat of banana was $1.05 \%$ which also supports the present value. The moisture content inthe pulp of banana varieties is also shown in Table 2. High moisture content food items are more susceptible to microbial attack and a shorter shelf life (Adepoju, 2012). The Shail variety contained the highest amount of moisture $(76.23 \%)$ whereas the Bichi variety contained less moisture $(73.49 \%)$. The approximate moisture content of Embul, Seeni and Kolikuttu varieties of banana at the harvest maturity were $77.86 \%, 72.46 \%$ and $75.97 \%$ respectively, according to Wasala, Dharmasena, Dissanayake, and Thilakarathne (2012) which supports the present study. Similar values were reported by Kachru, Kotwaliwale, and Balasubramanian (1995) for some Indian banana varieties at maturity. Auta and Kumurya (2015) found the moisture content of banana to be $73.63 \%$. According to Ikegwu and Ekwu (2009), the moisture content of fruits has an impact on a number of engineering properties. Fraser, Verma, and Muir (1978) indicate that the moisture content of agricultural produce dominances their bulk density. The ash content of banana varieties is also shown in Table 2. A high percentage of ash is indicative of a high mineral content, particularly the macro-minerals (Adeolu \& Enesi, 2013). Ash content was highest in the Champa variety at $1.05 \%$ while the Bichi variety contained the lowest amount of ash $(0.72 \%)$. The percentage of ash content of banana should be $4.93 \%$ according to Auta and Kumurya (2015) which was higher than the present study. The carbohydrate content of the banana varieties is also shown in Table 2. Carbohydrate could be a good source of energy for animals (Adeolu \& Enesi, 2013). The Bichi variety contained the highest carbohydrate $(22.71 \%)$ content, while the Champa variety contained $20.17 \%$ carbohydrate. According to the USDA National Nutrient data base, the carbohydrate percentage of banana pulp is $18 \%$. The total percentage carbohydrate content of banana found by Auta and Kumurya (2015) was $22.01 \%$.

\subsection{Sensory evaluation of jelly}

Sensory evaluation results for jellies which were made from the pulp of the four banana varieties are shown in Table 3. Reducing sugars and amino acids are responsible for the Maillard reaction that provides food flavor and a desirable brown color. Sucrose was the main ingredient for the production of the jellies to provide a sweet taste and contribute to jelly formation (Silva, Lacerda, Santos, \& Martins, 2008). A previous study found that fat content influences the taste (Bus \& Worsley, 2003). The color of jelly prepared from the Champa variety was the best while the color of jelly of the Bichi variety was not accepted by the panelists. The panelists described the jelly from the Champa variety as having a fascinating color that was more attractive to the eye compared with the darker color of the jelly from the Bichi variety. As color is of primary importance in consumers' acceptability of a product, the color of the jelly of the Bichi variety should be improved. The aroma score was highest $(6.4 \pm 0.52)$ in the jelly prepared from the Bichi variety which may be due to the higher carbohydrate content. The bitterness scores of the jelly from all banana varieties were almost average. The taste of the jelly prepared from the Bichi variety $(6.25 \pm 0.46)$ was the best but not much better than the taste of the jelly prepared from the Shail variety. The jelly prepared from the Shail variety showed the highest overall acceptance $(6.8 \pm 0.42)$.

\section{Conclusion}

The study showed that the Shail, Bichi, Champa and Sagor banana varieties of the Sylhet region in Bangladesh contained appreciable levels of nutrients. The Shail variety had the highest antioxidant activity as determined by the total phenolic content and DPPH scavenging activity, and contained the highest carbohydrate content and a protein content which was higher than in the Bichi variety. Among the jellies prepared from the banana varieties, the jelly of Shail variety showed the highest overall acceptance among the panelists. The peel of the bananas well as the pulp is a good source of antioxidants which may 
help reduce the risk of a variety of chronic diseases. Banana is widely available in Bangladesh and can be found throughout the year. Both the pulp and peel of banana offer new product development opportunities in the food, cosmetics and pharmaceutical industries.

\section{References}

Adeolu, A. T. \& Enesi, D. O. (2013). Assessment of proximate, mineral, vitamin and phytochemical compositions of plantain (Musa paradisiaca) bract-an agricultural waste. International Research Journal of Plant Science, 4(7), 192-197.

Adepoju, O. T. (2012). Nutrient composition, antinutritional factors and contribution of enriched dry guinea corn (Sorghum sp) leaf extract to nutrient intake of nigeria consumers. In Proc. intern. conf environ, biomed \& biotech ipcbee aug (pp. 4-5).

Alkarkhi, A. F. M., Saifullah, R., Yong, Y., \& Azhar, M. E. (2010). Physicochemical properties of banana peel flour as influenced by variety and stage of ripeness: multivariate statistical analysis. Asian Journal of Food and Agro-Industry, 3(3), 349-362.

Alothman, M., Bhat, R., \& Karim, A. A. (2009). Antioxidant capacity and phenolic content of selected tropical fruits from malaysia, extracted with different solvents. Food Chemistry, 115(3), 785-788. doi:10 . 1016/ j . foodchem.2008.12.005

American Association of Cereal Chemists. (2000). Approved methods of the american association of cereal chemists. AACC. Retrieved from https://books.google.pt/ books?id=xJwQAQAAMAAJ

Amorim, E. L. C., Nascimento, J. E., Monteiro, J. M., Peixoto Sobrinho, T. J. S., Araújo, T. A. S., \& Albuquerque, U. P. (2008). A simple and accurate procedure for the determination of tannin and flavonoid levels and some applications in ethnobotany and ethnopharmacology. Functional Ecosystems and Communities, 2(1), 88-94.

Anhwange, B. A., Ugye, T. J., \& Nyiaatagher, T. D. (2009). Chemical composition of Musa sapientum (banana) peels. Electronic
Journal of Environmental, Agricultural and Food Chemistry, 8(6), 437-442.

Association of the Official Analytical Chemists. (2004). Official methods of analysis of AOAC International. 20th ed., Washington, USA: AOAC.

Aurore, G., Parfait, B., \& Fahrasmane, L. (2009). Bananas, raw materials for making processed food products. Trends in Food Science \& Technology, 20(2), 78-91. doi:10. 1016/j.tifs.2008.10.003

Auta, S. A. \& Kumurya, A. S. (2015). Comparative proximate, mineral elements and anti-nutrients composition between musa sapientum (banana) and musa paradisiaca (plantain) pulp flour. Sky Journal of Biochemistry Research, 4 (4), 025-030.

Baskar, R., Shrisakthi, S., Sathyapriya, B., Shyampriya, R., Nithya, R., \& Poongodi, P. (2011). Antioxidant potential of peel extracts of banana varieties (Musa sapientum). Food and Nutrition Sciences, 2(10), 1128-1133. doi:10.4236/fns.2011.210151

Bus, A. E. M. \& Worsley, A. (2003). Consumers' sensory and nutritional perceptions of three types of milk. Public Health Nutrition, 6 (2), 201-208. doi:10.1079/PHN2002417

Chang, S. T., Wu, J. H., Wang, S. Y., Kang, P. L., Yang, N. S., \& Shyur, L. F. (2001). Antioxidant activity of extracts from acacia confusa bark and heartwood. Journal of Agricultural and Food Chemistry, 49(7), 3420-3424. doi:10.1021/jf0100907

Choo, C. L. \& Aziz, N. A. A. (2010). Effects of banana flour and beta-glucan on the nutritional and sensory evaluation of noodles. Food Chemistry, 119(1), 34-40. doi:10 . 1016/j.foodchem.2009.05.004

Coe, F. G. \& Anderson, G. J. (1999). Ethnobotany of the sumu (Ulwa) of southeastern nicaragua and comparisons with miskitu plant lore. Economic Botany, 53(4), 363386. doi:10.1007/BF02866715

Fatemeh, S. R., Saifullah, R., Abbas, F. M. A., \& Azhar, M. E. (2012). Total phenolics, flavonoids and antioxidant activity of banana pulp and peel flours: influence of variety and stage of ripeness. International Food Research Journal, 19(3), 1041. 
Fraser, B. M., Verma, S. S., \& Muir, W. E. (1978). Some physical-properties of fababeans. Journal of Agricultural Engineering Research, 23(1), 53-57. doi:10.1016/0021-8634(78)90079-3

Gonzalez-Montelongo, R., Gloria Lobo, M., \& Gonzalez, M. (2010). The effect of extraction temperature, time and number of steps on the antioxidant capacity of methanolic banana peel extracts. Separation and Purification Technology, 71(3), 347-355. doi:10.1016/j.seppur.2009.12.022

Ikegwu, O. J. \& Ekwu, F. C. (2009). Thermal and physical properties of some tropical fruits and their juices in nigeria. Journal of Food Technology, 7(2), 38-42.

Kachru, R. P., Kotwaliwale, N., \& Balasubramanian, D. (1995). Physical and mechanical-properties of green banana (musa-paradisiaca) fruit. Journal of Food Engineering, 26(3), 369-378. doi:10.1016/ 0260-8774(94)00054-D

Kanazawa, K. \& Sakakibara, H. (2000). High content of dopamine, a strong antioxidant, in cavendish banana. Journal of Agricultural and Food Chemistry, 48(3), 844-848. doi:10.1021/jf9909860

Lim, Y. Y., Lim, T. T., \& Tee, J. J. (2007). Antioxidant properties of several tropical fruits: a comparative study. Food Chemistry, 103(3), 1003-1008. doi:10.1016/j . foodchem.2006.08.038

Macheix, J. J., Fleuriet, A., \& Billot, J. (1990). Fruit phenolics. Boca Raton, FL, CRC Press.

Maisuthisakul, P., Suttajit, M., \& Pongsawatmanit, R. (2007). Assessment of phenolic content and free radical-scavenging capacity of some thai indigenous plants. Food Chemistry, 100(4), 1409-1418. doi:10. 1016/j.foodchem.2005.11.032

Nguyen, T., Ketsa, S., \& van Doorn, W. (2003). Relationship between browning and the activities of polyphenol oxidase and phenylalanine ammonia lyase in banana peel during low temperature storage. Postharvest Biology and Technology, 30(2), 187-193. doi:10.1016/S0925-5214(03)00103-0

Okonogi, S., Duangrat, C., Anuchpreeda, S., Tachakittirungrod, S., \& Chowwanapoon- pohn, S. (2007). Comparison of antioxidant capacities and cytotoxicities of certain fruit peels. Food Chemistry, 103(3), 839846. doi:10.1016/j.foodchem.2006.09.034

Olalekan, A. J. \& Ayodeji, K. E. (2010). Antioxidative potentials of banana and plantain peel extracts on crude palm oil. Ethnobotanical Leaflets, (5), 1.

Plemmons, L. E. \& Resurreccion, A. V. A. (1998). A warm-up sample improves reliability of responses in descriptive analysis. Journal of Sensory Studies, 13(4), 359376. doi:10 . $1111 /$ j . 1745 - 459X . 1998. tb00095.x. eprint: https: / / onlinelibrary. wiley.com/doi/pdf/10.1111/j.1745-459X. 1998.tb00095.x

Ravichandran, R. \& Parthiban, R. (2000). Lipid occurrence, distribution and degradation to flavour volatiles during tea processing. Food Chemistry, 68(1), 7-13. doi:10.1016/ S0308-8146(99)00143-0

Silva, M. R., Lacerda, D. B. C. L., Santos, G. G., \& Martins, D. M. d. O. (2008). Chemical characterization of native fruits of the cerrado. Rural Science, 38, 1790-1793. doi:10. 1590/S0103-84782008000600051

Sisler, E. C., Alwan, T., Goren, R., Serek, M., \& Apelbaum, A. (2003). 1-substituted cyclopropenes: effective blocking agents for ethylene action in plants. Plant Growth Regulation, 40(3), 223-228. doi:10.1023/A: 1025080420990

Someya, S., Yoshiki, Y., \& Okubo, K. (2002). Antioxidant compounds from bananas (Musa Cavendish). Food Chemistry, 79(3), 351354. doi:10.1016/S0308-8146(02)00186-3

Subhasree, B., Baskar, R., Keerthana, R. L., Susan, R. L., \& Rajasekaran, P. (2009). Evaluation of antioxidant potential in selected green leafy vegetables. Food Chemistry, 115(4), 1213-1220. doi:10.1016/j . foodchem.2009.01.029

Sun, J., Chu, Y.-F., Wu, X., \& Liu, R. H. (2002). Antioxidant and antiproliferative activities of common fruits. Journal of Agricultural and Food Chemistry, 50(25), 7449-7454. PMID: 12452674. doi:10.1021/jf0207530. eprint: https://doi.org/10.1021/jf0207530

Umamaheswari, M. \& Chatterjee, T. K. (2008). In vitro antioxidant activities of the frac- 
Banana varieties available in Sylhet region $\mid 97$

tions of coccinia grandis 1. leaf extract. African Journal of Traditional Complementary and Alternative Medicines, 5(1), 61-73.

Wasala, W. M. C. B., Dharmasena, D. A. N., Dissanayake, T. M. R., \& Thilakarathne, B. M. K. S. (2012). Physical and mechanical properties of three commercially grown banana (Musa acuminata Colla) cultivars in sri lanka. Tropical Agricultural Research, $24(1), 42-53$.

Zhang, P., Whistler, R. L., BeMiller, J. N., \& Hamaker, B. R. (2005). Banana starch: production, physicochemical properties, and digestibility-a review. Carbohydrate Polymers, 59(4), 443-458. doi:10.1016/j. carbpol.2004.10.014 